\title{
How Do Young People Respond to Conflict? A Comparative Study of Argentinean and Portuguese College Students1
}

\author{
Ana Maria Costa e Silva \\ Professor of Institute of Education \& Researcher of CECS-UMinho - Portugal \\ Prof. Florencia Brandoni \\ Professor of UNTREF - Argentina \\ Prof. Eduardo Duque \\ Professor of Catholic University \& Researcher of CECS-UMinho - Portugal
}

\begin{abstract}
Questions relating to sociability, relationships concerning conflicts and behaviours of indiscipline and violence among young people have turned out to be of particular importance. Various studies exist about the sociability of young people (e.g. Machado Pais, 1990; Margulis \& Urresti, 1998; Cangilini, 2004). Nevertheless, studies focused on sociability and behavior in the face of socially learned conflicts in the context of inter-personal relationships are still very scarce. The investigation carried out falls within the area of Co-operative Conflict Resolution (CCR) - a field of knowledge and practices that emerged in the 1980s (Ury \& Fisher, 1991; Aréchaga, Brandoni \& Finkelstein, 2004). The work that we present shows the results of a study undertaken with young people attending the first year of university education in public and private universities in Argentina and Portugal. This investigation, which was of an exploratory nature, had two general objectives: i) to analyse the ways of approaching conflicts by young people (aged 18 to 31 years); and ii) to understand the present day social dynamics that characterise these young people. The descriptive analysis of the data, which was obtained from the responses to a questionnaire with open and closed questions completed by around 700 young university students, revealed some differences concerning the behaviour adopted towards conflicts by these young Argentineans and young Portuguese.
\end{abstract}

Keywords: Sociability; Relationships; Conflicts; Young people; Co-operative Conflicts Resolution

\section{Introduction}

Studies on sociability and the building of personal identities of adolescents and young people (Efron, 1996; Dubar, 1998; Frigerio, 2004; Berger \& Luckman, 2008 among others) highlight the importance of establishing links with peers, of representations constructed of themselves and the way that others view them. For teenagers and young people the establishment of relationships and building links with their peers is particularly significant in the process of building their own personal identities (Efron, 1996; Dubar, 1998).

The subjects' building of their own personal identities also proceeds by means of identifications (Dubar, 1998). This is both a mental and social process, by which each person's identity is formed and transformed by assimilating or appropriating aspects and attributes of those around them (Frigerio, 2004; Berger \& Luckman, 2008). We can say that the personal identity of the subject is constructed and reconstructed on the basis of the relationship and interaction with others, in interdependence with culture (Canglini, 2004).

In the case of adolescents and young people, the exchanges that they establish within reference groups are particularly important, given that they can contribute to strengthening or weakening their process of identity-building and subjectivity.

${ }_{1}^{1}$ Translation from Portuguese into English of this article was funded by COMPETE: POCl-01-0145-FEDER-007560 and FCT Foundation for Science and Technology, under the project: UID / CCl / 00736/2013. 
This process of construction of subjectivity, associated with cultural stimuli, fosters their ways of being in the world. Sociability circuits include institutions, which also foster socialisation, assuming understanding and internalisation of the world as a meaningful and social reality (Berger \& Luckman, 2008), implying the incorporation of rules, norms, values and skills that make up the identity and definition of otherness, generating senses of belonging and modes of incorporation in social spaces (Dubar, 1998).

Studies on young people address their behaviour patterns with different social actors - peers, adults, significant adults, hierarchical superiors, social representatives - and their conduct in relation to conflict management. Machado Pais (1998) states in relation to young people the loss of meaning and historical continuity, which leads them to minimise a vision of the future, life projects and long-term relationships. As a result young people live primarily in the present, focusing their attention on themselves. Kessler (2004) points out that in the case of young people in conflict with the law, there is a clear need to "take advantage", i.e. to compete and achieve the desired goal at any price.

The question of gender is another important aspect to take into consideration in relation to sociability and the behaviour of young people in situations of conflict. According to Coria (2008), gender defines a different position in relation to attributes, sociability circuits, relationship modes, conflict management and negotiating attitudes.

Social representations often arise, associating young people to dangers, victimisation, individualism and lack of productivity. These representations stigmatise and conceal the rich diversity of specific young people and their particular socio-historical context, which contributes to fostering a demonisation of young people in the social imaginary universe, simplifying the reasons for violence, sometimes in an extreme form (Reguillo, 2007). However, young people are produced and moulded by the hegemonic spaces allocated to them and they also construct their own personal identities, by disputing, reproducing or negotiating the established social order (Vila, Infantino \& Castro, 2011).

The research carried out and the respective interest of such research is underpinned by the importance of identifying ways of internalising and addressing conflicts in order to conceive prevention and capacity-building strategies for young people, in order to approach them in a positive and cooperative manner. In this sense, the current study falls within the framework of Cooperative Conflict Resolution (CCR) - a recent field of study and intervention, which first appeared in the 1980s.

In this context, methods and devices of collaborative negotiation, facilitation and mediation of situations of conflict have been developed (Ury \& Fischer, 1991; Folger \& Taylor, 1992; Aréchaga, Brandoni \& Finkelstein, 2004; Brandoni, 2015). The increased attention to this field of enquiry and practices derives from growing discontent with traditional forms of justice administration and conflict resolution because of the respective delays, costs and consequences, which thereby often accentuate reactive and violent behaviour. At the same time, cooperative conflict resolution, such as mediation, is presented as a means and a process that values communication, cooperative dialogue and recognition of the other, thus contributing to forms of conviviality and sociability of rehabilitation and consolidation of social ties (Zabatel, 1999).

We know how conflictual and violent behaviour are currently experienced and denounced in different contexts: interpersonal, organisational, social and community. The media are powerful communicators of the consequences of such behaviour patterns, which are currently reflected in violent extremism, with serious consequences at the national and international level. Systematic and massive dissemination often has a negative final impact on social representations and behaviour patterns, thus accentuating radicalism and violent extremism.

One of the goals of Sustainable Development in the world by 2030 is to "promote peaceful and inclusive societies for sustainable development, provide access to justice for all and build effective, accountable and inclusive institutions at all levels" as a result of which the fields of research and education face strong challenges, in order to foster solidarity, justice and peace.

The current study has been drawn up to prepare an initial approach with university students, to inquire about how they perceive conflict situations and address conflict between peers and adults, in order to identify and propose appropriate intervention strategies for the education and training of young people in a positive and cooperative approach to conflict. The search for consensus, reconciliation and the integration of the interests of different social actors are considered to require specific knowledge and skills. Such knowledge and skills are scarce in the educational plans of children and young people, and only rarely occur in social exchanges and in the social imaginary universe. The media often cultivates a representation that associates adolescents and young people with violence, danger and an absence of limits. 
In this article we will refer to some of the results of a study conducted in 2015 with young Portuguese and Argentinean university students.

\section{Methodology}

\section{1 Objectives, methods and techniques}

Based on a brief theoretical context that was previously conducted, the current study focuses on a mixed methodology quantitative and qualitative - in order to collect information from a large group of subjects and advance some information from respondents who were willing to participate in group and / or individual interviews.

In order to study forms of sociability and conflict approaches of young people, various objectives were defined, including the following: i) analyse the ways of approaching conflicts by young people (aged 17 to 31 years); ii) understand the present day social dynamics that characterise these young people; iii) compare the results of this study with other studies on the social representations and practices of young people; iv) provide information on the necessary conditions to design capacity-building programmes, aimed at fostering a positive and cooperative approach towards conflict and mediation.

\section{2 Data collection instrument and procedures}

Information has been collected so far by means of a survey questionnaire entitled "Questionnaire on conflict management" prepared by Argentinean students and researchers under the supervision of the researcher, Florencia Brandoni (2014), translated and adapted into Portuguese by the researcher Ana Maria Silva (2014).

The questionnaire consists of a total of twenty questions: two open questions, eighteen closed questions (four with a response option, if answered affirmatively) and five conflict situations, in relation to which they are asked what the respondent would do if they found themselves in the respective situation.

The questions included in the questionnaire focused on the following dimensions: situations that are considered to be confrontational and violent; causes of conflicts with adults and peers; the connotation attributed to conflicts; behaviour patterns in situations of conflict with adults and peers; perception about the social imaginary universe related to conflict; perception of socially-installed procedures for conflict resolution.

Data was collected in Portugal (Braga) and Argentina (Buenos Aires) in early 2015. In both countries the questionnaire was applied in a public university and a private university. For this purpose, consideration was made of the researchers' access to the potential respondents.

The questionnaire was applied collectively in the classroom, and took about 30 minutes to fill out. Students were invited to participate in an international study on conflict management and sociability. The cover page of the questionnaire explained the study's objectives. The students were thanked for their participation and the confidentiality of the responses was also guaranteed. Replies to the questionnaires were anonymous and voluntary. Respondents were solely asked to identify their sex and age. Nevertheless, respondents who were interested in participating in group or individual interviews could identify themselves.

\section{3 Set of respondents}

The respondents to the questionnaire were university students from different courses, attending the first year of higher education.

In Argentina they were students from the University Nacional Tres de Febrero (UNTREF) and the University of San Andrés, both located in Buenos Aires, involving a total of 256 university students (133 women and 123 men), aged between 17 and 31 years from fifteen different courses.

In Portugal they were students from the University of Minho (UMinho) and the Catholic University, both located in the city of Braga, involving a total of 453 university students (338 women and 115 men), aged between 17 and 31 years old, from seventeen courses. The mean age of respondents in the two countries was 20 years old. 
Table 1. Breakdown of the set of respondents

\begin{tabular}{|l|l|l|l|l|}
\hline Country & $\begin{array}{l}\text { Total number of } \\
\text { respondents }\end{array}$ & Women & Men & Average age \\
\hline Argentina & 256 & 133 & 123 & 21 \\
\hline Portugal & 453 & 338 & 115 & 19 \\
\hline Total & 709 & 471 & 238 & 20 \\
\hline
\end{tabular}

Table 1 reveals that the set of respondents from both countries involved 709 respondents, of which 471 were women and 238 men. The highest proportion of women in the sample, namely Portugal, reflects the current reality of the Portuguese higher education system.

\section{Presentation and discussion of results}

The goals underlying the questions formulated in the questionnaire were on the one hand to understand how young people perceive conflict situations in the social environment in which they live; on the other hand, the way that they react and act when confronted with conflict situations in their personal lives.

Given the total amount of information that has been collected this article presents the results for the dimension Behaviour patterns of young people in conflict situations with peers and adults. The information was collected via three questions: two closed questions and one with five situations regarding which the respondent was asked what he or she would do in that situation.

\section{1 Behaviour when faced by conflict with other young people}

For the question: What behaviour do you use most often in conflict with other young people? the respondents were presented with 16 options, from which they could choose up to five responses or add others. Table 2 presents the response options.

Table 2. Response options for the most frequently used behaviour by young people and adults

Options

\begin{tabular}{l|l}
\hline 1 & Compete with the other \\
\hline 2 & Give up your claim in favour of the other \\
\hline 3 & Seek an agreement, based on the differences \\
\hline 4 & Seek to impose your position \\
\hline 5 & Support the other's decision \\
\hline 6 & Use physical force \\
\hline 7 & Forget the conflict \\
\hline 9 & Seek help or someone to resolve the conflict for you \\
\hline 10 & Seek allies to increase power and impose your position \\
\hline 11 & Become infuriated and imagine how to get revenge \\
\hline 12 & Threaten \\
\hline 13 & Hinder or obstruct the other's actions \\
\hline 14 & Reconsider your position \\
\hline 15 & Avoid conflict \\
\hline 16 & Talk and listen to the other \\
\hline Althougue to convince the other
\end{tabular}

Although two of the variables assumed in the study were sex and age, there were no significant differences between the young respondents in Argentina or in Portugal for these variables. Most of the young Portuguese people stated that the behaviour patterns they most often choose when they face a conflict situation with another young person are to dialogue and listen to the other (56,5\%), avoid the conflict (53,9\%) and seek an agreement, splitting the differences (53,6\%); at a less expressive level, but other response options that were also valued by the surveyed young people were as behaviours forget the conflict $(40,6 \%)$ and reconsider the position $(30,5 \%)$. Options such as undermine or create obstacles for the other's actions (2,6\%) and threaten (4,2\%) were behaviours that had fewer supporters among the young people. Most of the young Argentineans preferred to impose your position (72,2\%), followed by dialogue and listen to the other (66,8\%). 
The option avoid the conflict had the lowest number of supporters $(5,9 \%)$. In table 3 , we can see the total percentages of responses to each option in both countries.

Table 3. Percentage breakdown of responses to the question: What is your most frequently used behaviour in situations of conflict with young people

\begin{tabular}{l|l|l|l} 
& \multirow{2}{*}{ Options } & $\%$ & \multicolumn{2}{l}{} \\
& & Argentina & Portugal \\
\hline 1 & Compete with the other & 27,3 & 10,4 \\
\hline 2 & Give up your claim in favour of the other & 36,7 & 9,5 \\
\hline 3 & Seek an agreement, based on the differences & 36,7 & 53,6 \\
\hline 4 & Seek to impose your position & 72,2 & 19,6 \\
\hline 5 & Support the other's decision & 40,6 & 21,2 \\
\hline 6 & Use physical force & 24,6 & 7,5 \\
\hline 7 & Forget the conflict & 45,3 & 40,6 \\
\hline 8 & Seek help or someone to resolve the conflict for you & 26,2 & 4,4 \\
\hline 9 & Seek allies to increase power and impose your position & 32,8 & 7,5 \\
\hline 10 & Become infuriated and imagine how to get revenge & 21,1 & 8,8 \\
\hline 11 & Threaten & 21,9 & 4,2 \\
\hline 12 & Hinder or obstruct the other's actions & 21,5 & 2,6 \\
\hline 13 & Reconsider your position & 44,9 & 30,5 \\
\hline 14 & Avoid conflict & 5,9 & 53,9 \\
\hline 15 & Talk and listen to the other & 66,8 & 56,5 \\
\hline 16 & Dialogue to convince the other & 56,3 & 29,1 \\
\hline & & & \\
\hline
\end{tabular}

Comparing the response rates to the various options emphasises the differences related to options 4 and 14 , which show the differences in behaviour in situations of conflict of the young Argentinean and Portuguese respondents and we will later analyse this question, comparing the behaviour in situations of conflict with young people and adults.

\section{2 Behaviour in situations of conflict with adults}

The same question was formulated regarding the behaviour of respondents in situations of conflict with adults. They were given the same response options, except for option 14, in which the option 'avoid the conflict' was replaced by 'obey'. Table 4 shows the response rates for each of the options by the young people in each country.

Comparison of the results for young people in both countries reveals several differences, some of which are more accentuated in the responses to the various options, as can be seen in table 4. These differences make it possible to give consistency to the differences noted by the young Argentinean and Portuguese respondents relating to behaviour with young people. 
Table 4. Percentage breakdown of responses to the question: What is your most frequently used behaviour in situations of conflict with adults

\begin{tabular}{l|l|l|l} 
& \multirow{2}{*}{ Options } & $\%$ & \multicolumn{2}{l}{} \\
\cline { 4 - 4 } & & Argentina & Portugal \\
\hline 1 & Compete with the other & 16,8 & 4,9 \\
\hline 2 & Give up your claim in favour of the other & 31,3 & 18,1 \\
\hline 3 & Seek an agreement, based on the differences & 32 & 48,8 \\
\hline 4 & Seek to impose your position & 60,9 & 25,4 \\
\hline 5 & Support the other's decision & 50,8 & 31,3 \\
\hline 6 & Use physical force & 14,8 & 2,4 \\
\hline 7 & Forget the conflict & 44,1 & 44,6 \\
\hline 8 & Seek help or someone to resolve the conflict for you & 20,7 & 3,8 \\
\hline 9 & Seek allies to increase power and impose your position & 26,2 & 9,3 \\
\hline 10 & Become infuriated and imagine how to get revenge & 15,6 & 5,5 \\
\hline 11 & Threaten & 14,8 & 2,0 \\
\hline 12 & Hinder or obstruct the other's actions & 13,7 & 2,2 \\
\hline 13 & Obey & 41 & 35,1 \\
\hline 14 & Talk and listen to the other & 60,5 & 68 \\
\hline 15 & Dialogue to convince the other & 67,2 & 49,7
\end{tabular}

The attitude that the surveyed young people assume before a situation of conflict with other young people is identical to that chosen by them when it comes to a situation of conflict with adults, since $68 \%$ of young Portuguese and $60.5 \%$ of young Argentineans stated that they prefer to talk and listen in a situation of conflict with someone older, whereas $49.7 \%$ and $67.2 \%$ respectively opted to dialogue to convince; $48,8 \%$ of young Portuguese chose to seek an agreement, based on the differences and $44,6 \%$ prefer to forget the conflict, while $60,9 \%$ of young Argentineans seek to impose their position in relation to adults. Options such as undermine or create obstacles for the other's actions, threaten or use physical force were also the behaviour patterns least chosen by the young people of both countries in their conflict with adults. This attitude towards adults shows that there is a prejudice in relation to conflicts between different generations.

The options offered were grouped into five categories corresponding to different styles of behaviour in situations of conflict: i) compete ii) give in, iii) evade iv) dialogue, v) become hostile.

Table 5 shows the results obtained for the five behaviour patterns considered. The results show that a significant percentage (42\%) of young Argentineans assumes dialogue as a behaviour that is more frequently used both with young people and with adults, while the young Portuguese reveal that the behaviour most used in conflicts with other young people is evasion (47.3\%) whereas the behaviour most used in conflict with adults is dialogue. It should also be pointed out that young Portuguese have the highest percentages in these two behaviour patterns both in relation to young people and adults, whereas the other behaviour patterns have much lower percentages, wherein becoming hostile and use of force are the least representative in the responses (5, $8 \%$ and $3 \%$ respectively). 
Table 5. Behaviour of young Argentineans and Portuguese in situations of conflict with other young people and with adults

\begin{tabular}{l|l|l|l|l|l}
\multirow{2}{*}{ Behaviours } & \multirow{2}{*}{ Options } & \multicolumn{2}{|l|}{ Behaviour with young people } & \multicolumn{2}{l}{ Behaviour with adults } \\
\cline { 3 - 6 } & & Argentina & Portugal & Argentina & Portugal \\
\hline Compete & $1,4,9$ & $15 \%$ & $12,5 \%$ & $14,6 \%$ & 13,2 \\
\hline Give in & 2,5 & $12 \%$ & $15,4 \%$ & $24 \%$ & 24,7 \\
\hline Evade & 7,14 & $16 \%$ & $47,3 \%$ & $8,6 \%$ & 39,6 \\
\hline Dialogue & $3,8,13,15,16$ & $42 \%$ & $34,8 \%$ & $40,8 \%$ & 42,6 \\
\hline Become hostile & $6,10,11,12$ & $14 \%$ & $5,8 \%$ & $11,5 \%$ & $3 \%$
\end{tabular}

The young Argentineans present options that are distributed evenly across the various behaviour patterns, whereas dialogue clearly prevails, both in terms of behaviour with young people (42\%), and with adults (40.8\%).

\section{3 Behaviour of young people in situations of conflict}

To further identify the behaviour patterns of young people in situations of conflict, five situations were presented in order to enable young people to state how they would deal with such situations. In a specific manner, the young people were led to reflect about concrete situations of conflict that are likely to happen in their lives, wherein a response was presented to each of them concerning the behaviour that they would adopt. The situations ranged from experiences of conflict with other young university colleagues or closer friends, such as teachers, employers and other adults. Table 5 describes the various situations.

Table 5. Situations for young people to identify how they will respond to them

Description of the situations

In the Curricular Unit (UC) of Contemporary Culture, you have been asked to work in pairs. You ask João to work with you, since you to believe that he is a friendly and responsible young man. He gets on well with you

Situation A and accepts your offer. Given your working hours and the days of the class, you can only meet up at the weekend. On Saturday, you play a sports championship with your friends, but on Sunday you are to meet with João. However João spends every Sunday with his family and girlfriend, so it can't be on that day. What do you do?

On the day you arrive to do a final test, on the last call for the test, you realise that your name isn't included on the list of enrolled students. You complain to the administrative officer in charge of the Academic

Situation B Services, with whom you have good relationship, and he says that the professor is responsible for the situation. You enter the room, you see the professor starting the test, and he says that he can't authorise you to take the test, if you're not on the list, and that he distributed the notes in due time. What do you do? The day before yesterday, you met with Mariana, a friend of yours, who commented that she saw your

Situation C boyfriend/girlfriend in the mall at the weekend. After beating around the bush, she says that her cousin told her that s/he met your boyfriend/girlfriend and spent the night with him/her. What do you do?

After a long period of searching and waiting, you secure a job in a shop. The work agreement is only to serve customers. You don't like the shop's owner very much, but an employee who has been working there for a

Situation D year seems nice. After a week, the owner asks you clean the shop's basement and you don't like this request, because it wasn't in your initial agreement. He tells you that the other employee doesn't want to keep on doing this task. What do you do?

You arrive at your house and you see that the neighbour of the apartment at the end of the building has once again left the car parked on the pavement. You're already sick and tired of telling him that the pavement can't

Situation $\mathrm{E}$ support the weight and will break the bricks, as has happened in the past. Having to change the bricks leads to inconvenience, complications and expenses. Moreover, the car obstructs the entrance and exit to your house. You ring the bell and ask the neighbour to move his car and, without letting you speak, he starts screaming threateningly. What do you do?

After a general reading of the various situations, we realise that the surveyed young people sought, in all cases, to provide adequate responses that could solve the problems that they faced. The responses more frequently chosen by the young 
Portuguese people for each of the situations, after analysis of the data, were in line with the type of responses presented in the previous questions, related to the behaviour that they wood choose before situations of conflict either with other young people, or with adults.

The following table presents the responses with the highest percentages for young Argentinean and Portuguese people in each situation.

Table 6. Behaviour of young Argentinean and Portuguese people in the different situations

\begin{tabular}{l|l|l|l} 
Situations & Responses & $\begin{array}{l}\text { Young Argentineans } \\
\%\end{array}$ & $\begin{array}{l}\text { Young Portuguese } \\
\%\end{array}$ \\
\hline $\mathrm{A}$ & Negotiate & 76 & 68 \\
\hline \multirow{3}{*}{$\mathrm{B}$} & Dialogue & 11 & 27,8 \\
\cline { 2 - 4 } & Claim & 35 & 21,6 \\
\cline { 2 - 4 } & Compete & 48 & 12,2 \\
\hline $\mathrm{C}$ & Dialogue & 18 & 54,3 \\
\cline { 2 - 4 } & Evade & 40 & 13,9 \\
\hline \multirow{2}{*}{$\mathrm{D}$} & Give in & 43 & 21,2 \\
\cline { 2 - 4 } & Compete & 26 & 46,6 \\
\hline $\mathrm{E}$ & Claim & 49 & 10,2
\end{tabular}

Comparing the results of analysis of the responses given by the young Argentineans and Portuguese we observe the previously identified trend. However, the evasive behaviour manifested by the young Portuguese in the reactions to the conflict with young people and adults was less significant here, given that in situation $\mathrm{C}$ this response was only given by $13.9 \%$ of the respondents, but is more evident in young Argentineans with $40 \%$ of responses in the same situation.

\section{4 Discussion of the results}

The results above make it possible to identify similar behaviour in relation to the situations of conflict of young Argentineans and Portuguese people, wherein dialogue (with percentages between $34 \%$ and $43 \%$ ) is the behaviour that is most frequently chosen by young people and which is considered to be the most effective in terms of resolution of situations of conflict.

Table 7. Preferential behaviour of young people in conflict with other young people and with adults

\begin{tabular}{l|l|l|l|l}
\multirow{2}{*}{$\begin{array}{l}\text { Preference/Level } \\
\text { of effectiveness }\end{array}$} & Behaviour with young people & Behaviour with adults \\
\cline { 2 - 5 } & Argentina & Portugal & Argentina & Portugal \\
\hline $1^{\circ}$ & Dialogue & Evade & Dialogue & Dialogue \\
\hline $2^{0}$ & Evade & Dialogue & Give in & Evade \\
\hline $3^{0}$ & Compete & Give in & Compete & Give in \\
\hline $4^{0}$ & Become hostile & Compete & Become hostile & Compete \\
\hline $5^{\circ}$ & Give in & Become hostile & Evade & Become hostile
\end{tabular}

In the previous table it can be seen that the two most frequently used behaviour patterns are dialogue and evasion. The latter is more pronounced amongst the young Portuguese respondents, wherein for these young people the next most frequently used behaviour patterns are to give in, compete, become hostile, and use force, however with much smaller percentages than dialogue or evasion. Young Argentineans reveal that dialogue is the preferred behaviour pattern, followed by evasion, with a much lower level of response. To compete, become hostile and give in are the least commonly used behaviour patterns used by young Argentineans, but still with percentages that are similar to, or higher than, those of the young Portuguese respondents.

Notwithstanding the fact that dialogue and evasion represent a significant percentage, and therefore, represent a preferred behaviour pattern, the majority (between $57 \%$ and $66 \%$ ) of the surveyed young people were divided into two different behaviour patterns: more assertive or more evasive. 
In relation to the presented situations, a diversity of behaviour patterns was also recorded. Ranging between negotiate, seek alternatives and discuss, mainly, but also to give in, compete and claim. We note the frequent and natural use of distributive negotiation and also cost-benefit analysis (e.g. in the case of whether to give in, so as to keep the job). In the case of young Argentineans, conflicts that result in violence are conflicts between neighbours and loved ones. The percentage of the use of physical or verbal violence, even if lower, range between $20 \%$ and $4 \%$ when faced by the aggressive action of the interlocutor and in conflicts with loved ones. The results of the responses given to the situations require greater depth in the individual or group interviews that make it possible to assess with greater accuracy the responses given by the young people as well as the interpretation of the content of the responses.

\section{Final considerations}

The results obtained in the three questions relating to the behaviour patterns of young people in several situations of conflict before the various actors, it can be noticed that a significant percentage of young people prefer and/or recognise that dialogue and negotiation assume important levels of effectiveness in addressing and resolving conflicts, contrary to some studies that tend to associate behaviour patterns of increased aggression or violence with young people (Kessler, 2004). This study also does not demonstrate the significant differences in the responses between male and female respondents that have been shown in other studies (Coria, 2008). We can see some differentiation in the behaviour patterns among young people in the two countries: a tendency towards greater assertiveness and aggressiveness in the behaviour of young Argentineans and greater passivity and acceptance in the young Portuguese respondents. When we confront these results with the bi-directional model of Kilmann and Thomas (1977), we realise that a significant percentage of young Argentineans and Portuguese (about 40\%) adopt behaviour patterns that valorise negotiation, the search for compromises and dialogue, expressing a concern with oneself and with others. These are important results in order to socially validate a positive image of young people. As regards the remaining $60 \%$ of respondents there is a distribution between the different behaviour patterns, wherein competition is more accentuated amongst young Argentineans and escape or evasion amongst young Portuguese respondents. These results deserve attention and interest in order to be analysed in greater depth, especially in subsequent interviews and other specific tests.

\section{References}

[1] Aréchaga, P, Brandoni, F. \& Finkelstein, A. (2004). Acerca de la clínica de mediación. Buenos Aires: Librería Histórica.

[2] Berger, P. \& Luckmann, T. (2008). La construcción social de la realidad. Buenos Aires: Amorrortu.

[3] Brandoni, F. (2015). Mediation and Mediators: a new social practice. In A. M. Silva \& M. Aparicio, (Eds), International Handbook about Professional Identities (pp.294-317). USA: Scientific \& Academic Publishing.

[4] Canglini, N. (2004). Introducción. Teorías de la interculturalidad y fracasos políticos. In Diferentes, desiguales y desconectados, mapas de la interculturalidade. Bracelona: Gedisa.

[5] Coria, C. (2008). Las negociaciones nuestras de cada día. Buenos Aires: Paidós.

[6] Dubar, C. (1998). La socialisation. Construction des identités sociales et professionnelles. Paris: Armand Collin.

[7] Efrón, R. (1996). Subjetividad y adolescência. In I. Konterllnik \& C. Jacinto, Adolescencia, pobreza, educación y trabajo. Buenos Aires: Losada Unicef.

[8] Folberg, J \& Taylor, A. (1992). Mediación. Resolución de conflictos sin litígios. México: Limusa Noriega editores.

[9] Frigerio, G. (2004). Identidad es el otro nombre de la alteridad. La habilitación de la oportunidade. In G. Frigerio \& G. Diker (coords.), Una ética en el trabajo con niños y jóvenes, Buenos Aires: Novedades Educativas/CEM.

[10] Kessler, G. (2004) Sociología del delito amateur. Buenos Aires: Paidós,.

[11] Machado Pais, J. (1990). A construção sociológica da juventude. Análise Social, V. 25, 139-165. 
[12] Machado País, J. (1998). Chollos, chapuzas, changas jóvenes, trabajo precario y futuro. Bogoté: Ed Anthropos.

[13] Margulis, M. \& Urresti, M. (1998) La construcción social de la condición de juventud. In Margulis, M, (comp.), Viviendo a todo. Jóvenes, territorios, culturales y nuevas sensibilidades. Bogotá: Siglo del Hombre Editores.

[14] ONU (2015). Conheça os novos 17 Objetivos de Desenvolvimento Sustentável da ONU. Publicado em setembro de 2015, acedido em https://nacoesunidas.org/conheca-os-novos-17-objetivos-de-desenvolvimentosustentavel-da-onu/ a 19 julho de 2016.

[15] Kilmann, R. \& Thomas, K. (1977). Developing a Forced-Choice Measure of Conflict-Handling Behavior: The "Mode" Instrument, Educational and Psychological Measurement, Vol. 37, No. 2, 309-325.

[16] Reguillo, R. (2007). La mara: contingencia y afiliación con el exceso repensando los limites. In Las maras. Identidades juveniles al limite. México: Universidad Autónoma Metropolitana.

[17] Ury, W. \& Fisher, R. (1991). Sí, de acuerdo. Bogotá: Editorial Norma.

[18] Villa, A., Infantino, J. \& Castro, G. (comps) (2011). Culturas juveniles. Disputas entre representaciones hegemónicas y prácticas. Bienos Aires: NOVEDUC, ReiJA.

[19] Zabatel, E. C. (1999). Mediación: cambio social o más de lo mismo? In F. Brandoni (comp.) Médiación escolar. Propuestas, reflexiones y experiencias (pp.141-152). Buenos Aires: Paidós. 